\title{
Partial biochemical characterization of digestive proteases present in the gastric juices of two Chilean crustaceans, Lithodes santolla (Molina, 1782) and Cancer edwardsii (Bell, 1835)
}

\author{
Isaura Bañuelos-Vargas ${ }^{1}$, Fredy Cárdenas-Chávez ${ }^{2}$, Kurt Paschke ${ }^{3}$, José Cristóbal Román-Reyes ${ }^{1}$ \\ Jesús Aarón Salazar-Leyva ${ }^{4}$ \& Emmanuel Martínez-Montaño ${ }^{4,5}$ \\ ${ }^{1}$ Facultad de Ciencias del Mar, Universidad Autónoma de Sinaloa, Mazatlán, Sinaloa, México \\ ${ }^{2}$ Escuela de Acuicultura y Pesquerías, Universidad Austral de Chile, Puerto Montt, Chile \\ ${ }^{3}$ Instituto de Acuicultura, Universidad Austral de Chile, Puerto Montt, Chile \\ ${ }^{4}$ Maestría en Ciencias Aplicadas, Unidad Académica de Ingeniería en Biotecnología \\ Universidad Politécnica de Sinaloa, Mazatlán, Sinaloa, México \\ ${ }^{5}$ Cátedras CONACYT, Consejo Nacional de Ciencia y Tecnología, Ciudad de México, México \\ Corresponding author: Emmanuel Martínez-Montaño (emm_82@hotmail.com)
}

\begin{abstract}
The objectives of the present study were to characterize biochemically the proteases present in gastric juices from adults of the southern king crab (Lithodes santolla) and the Chilean rock crab (Cancer edwardsii), to determine the classes of proteases using specific inhibitors, as well as to evaluate the effect of temperature and $\mathrm{pH}$ that affect the proteolytic activity. The enzyme activity analysis revealed non-significant differences between the activities of serine proteases (trypsin and chymotrypsin) in both species. On the other hand, acid protease activity in C. edwardsii was significantly higher than in L. santolla. The activity of aspartate proteases was inhibited by Pepstatin A in both species, with no significant differences in the extent of inhibition between them. The maximal enzyme activity detected for both species occurred at alkaline $\mathrm{pH}$. The optimum $\mathrm{pH}$ for proteolytic activity was ranged between 7 and 9 for $C$. edwardsii, and between 7 and 11 for L. santolla. Moreover, the highest proteolytic activity was recorded at $60^{\circ} \mathrm{C}$ in both species. However, at this temperature, enzyme activity was unstable after 20 min. Finally, collagenase-like activity in the gastric juices was detected for both species; this activity deserves further investigation, considering its biotechnological potential.
\end{abstract}

Keywords: Lithodes santolla, Cancer edwardsii, digestive physiology, proteases, protein inhibitors, subpolar crabs.

\section{INTRODUCTION}

Crabs, such as stone crabs and lithodids, are economically valuable fishery resources from Polar and Subpolar regions (Calcagno et al., 2005; Lovrich \& Tapella, 2014). The southern king crab (Lithodes santolla) and the Chilean rock crab (Cancer edwardsii) are species that inhabit the southern tip of South America (Paschke et al., 2013; Vinuesa et al., 2013). Their natural populations have plummeted in recent years, and aquaculture production has become an option to meet the commercial demand for these products as well as to reduce the fishery overexploitation of these resources (Tapia et al., 2008; Paschke et al., 2013).

Grow-out nursery technology for $L$. santolla is relatively new compared to other crustacean species, and therefore requires research studies focused on nutrition and feeding aspects. Nowadays, the feeding of lithodids and crabs in captivity is based on the use of natural feeds such as small pelagic fishes (Woll \& Berge, 2007) and fresh mollusk meat from squids and mytilids (Calcagno et al., 2004). However, there are reports on the use of species-specific manufactured feed to maintain high survival and growth rates of the edible crab Cancer pagurus (Berge \& Woll, 2006) and the red king crab Paralithodes camtschaticus (James et al., 2013; Siikavuopio \& James, 2015). Nevertheless, it is well known that to successfully achieve a sustainable aquaculture for crustaceans, the development of formulated diets should be investigated (Cuzon et al., 1994).

Investigations focused on digestive physiology provide essential knowledge about feeding habits

Corresponding editor: Fernando Vega Villasante 
(Figueiredo \& Anderson, 2009) and digestive capacity (Buarque et al., 2010; Fernández-Gimenez, 2013) of organisms, and could be applicable to formulate species and stage-specific feeds. Thus, diet formulation should be performed considering feedstuffs that are suitable for digestion (Lindner et al., 1995), containing nutrients with a proper assimilation potential (bioavailability) (Márquez et al., 2013), and lacking anti-nutritional factors such as enzyme inhibitors, among many other factors. Numerous studies on digestive enzymes in marine crustaceans from tropical and temperate waters have been published; however, there is limited information on the biochemical characterization of cold-water crustacean species (Buchholz \& Vetter, 1993; Freese et al., 2012; Rojo et al., 2013), changes in digestive capacity through ontogeny (Saborowski et al., 2006), and the effects of starvation on digestive enzymes (Comoglio et al., 2008). It has been considered that analysis of digestive enzymes could be used as an indicator of the nutritional status in different ontogenetic stages, as well as the conditions of cultures in relation to feeding and other environmental variables.

Juveniles of $L$. santolla are macrophage and opportunistic omnivorous predators (Vinuesa et al., 2013), with a highly diverse diet composed of several species of algae, protists, and invertebrates. On the other hand, $C$. edwardsii are scavengers and omnivorous, preferably feeding on various species of mussels and others mollusks (Tapia et al., 2008). Considering the feeding habits, proteases are the most conspicuous enzymes involved in digestive processes in omnivorous species with a carnivory tendency such as L. santolla and C. edwardsii. Previously, Saborowski et al. (2006) and Galgani \& Nagayama (1987) analyzed the presence and activity of different digestive enzymes in L. santolla in early ontogenetic stages and in adults; nevertheless, to date a biochemical characterization of proteases evaluating the effect of various physical and biochemical conditions on enzyme activity has not been reported. For C. edwardii, this is the first report on the biochemical characterization of proteases contained in the gastric juices of these species.

Therefore, the aim of the present work was to compare the partial biochemical characterization of proteases contained in the gastric juices of the southern king crab ( $L$. santolla) and the Chilean stone crab $(C$. edwardsii). The findings derived from this study provide basic information about the digestive physiology of both crustacean species and will be useful in further nutritional and biotechnological research.

\section{MATERIALS AND METHODS}

\section{Specimens and sampling}

This research was performed using live adults in intermolt stage of $C$. edwardsii (body weight: $403 \pm 61$ g; carapace width: $8.4 \pm 0.4 \mathrm{~cm}$ ) and $L$. santolla (body weight: $774 \pm 222 \mathrm{~g}$; carapace width: $9.9 \pm 1.2 \mathrm{~cm}$ ) provided by the Laboratory of Crustacean Ecophysiology (LECOFIC) at the Universidad Austral de Chile, Chile. Crabs were maintained in tanks with a continuous flow of filtered seawater and were fed twice daily at 10:00 and 16:00 $\mathrm{h}$ with fresh meat of Chilean mussels, Mytilus chilensis. Twenty-four hours after the last meal and previous to the first feeding horary (10:00 AM), gastric juices were obtained separately from 12 starved specimens of each species. Then, three pools of gastric juices were formed (4 individuals per pools) for further analysis. Individual crabs were sampled by introducing a flexible Teflon tube through the esophagus to reach the gastric chamber and aspirating approximately 1 to $1.5 \mathrm{~mL}$ of gastric juices per individual with a micropipette (Saborowski et al., 2006; Rojo et al., 2013).

The $\mathrm{pH}$ of three pools (4 individuals per pool) of gastric juices was measured using a potentiometer immediately after extraction. Juices were immediately transferred to cool vials $\left(<4^{\circ} \mathrm{C}\right)$ and centrifuged at $10,000 \times g$ for $10 \mathrm{~min}$ at $4^{\circ} \mathrm{C}$ to remove potential debris. Supernatants were stored at $-80^{\circ} \mathrm{C}$ until use for enzyme analysis.

\section{Enzyme assays}

Soluble protein concentration was determined according to the method by Bradford (1976) using the Quick Start $^{\mathrm{TM}}$ (BIO RAD) protein assay kit, using bovine serum albumin as a protein standard. Alkaline proteolytic activity was quantified, as described by Sarath et al. (1989), using $2 \%$ (w/v) azocasein in 50 $\mathrm{mM}$ Tris- $\mathrm{HCl}$ buffer with $10 \mathrm{mM} \mathrm{CaCl} 2 \mathrm{pH} 9$ as substrate. Calcium chloride was used to maintain the stability of proteases (Tremacoldi et al., 2007). The concentration of azocasein here used has been previously used in crustacean studies (Figuereido et al., 2001). The reaction was initiated by adding $100 \mu \mathrm{L}$ of gastric juice to $150 \mu \mathrm{L}$ of substrate solution and incubated for $30 \mathrm{~min}$ at $37^{\circ} \mathrm{C}$. The reaction was stopped by adding $750 \mu \mathrm{L}$ of $10 \%(\mathrm{w} / \mathrm{v})$ trichloroacetic acid and incubating final volume $(1000 \mu \mathrm{L})$ for $30 \mathrm{~min}$ at $4^{\circ} \mathrm{C}$. The undigested substrate and enzyme precipitates were separated by centrifugation at $19,000 \mathrm{~g}$ for $5 \mathrm{~min}$. Supernatant absorbance was recorded at $366 \mathrm{~nm}$ (Lemos et al., 2000). One unit of alkaline proteolytic activity was defined as the amount of enzyme required to cause an increase of 0.1 absorbance per minute. Acid 
proteolytic activity was determined according to Sarath et al. (1989) using $300 \mu \mathrm{L}$ of $2 \%$ (w/v) bovine hemoglobin in $0.2 \mathrm{M}$ glycine- $\mathrm{HCl} \mathrm{pH} 3.0$ as substrate. Both gastric juices $(100 \mu \mathrm{L})$ and substrate were incubated at $37^{\circ} \mathrm{C}$, enzyme reaction stopped by adding $600 \mu \mathrm{L}$ of $5 \%(\mathrm{w} / \mathrm{v})$ trichloroacetic acid and the absorbance of reaction products was measured at 280 $\mathrm{nm}$. One unit of enzyme activity was defined as $1 \mu \mathrm{g}$ tyrosine released per minute, using the molar extinction coefficient of $0.005 \mathrm{~mL} \mathrm{\mu g}^{-1} \mathrm{~cm}^{-1}$.

Trypsin activity (EC 3.4.21.4) was measured according to the method by Erlanger et al. (1961), previously used on marine decapods by García-Carreño et al. (1994). Thus, $500 \mu \mathrm{L}$ of $1 \mathrm{mM}$ BAPNA $(\mathrm{N}-\alpha-$ benzoyl-DL-arginine- $p$-nitroanilide) dissolved in DMSO was brought to $50 \mathrm{~mL}$ with a buffer with $50 \mathrm{mM}$ Tris- $\mathrm{HCl}$ and $20 \mathrm{mM} \mathrm{CaCl}_{2} \mathrm{pH} 8.2$ was used as the substrate. The enzyme reaction was initiated by adding $80 \mu \mathrm{L}$ of gastric juices and stopped with $160 \mu \mathrm{L}$ of $30 \%$ $(\mathrm{w} / \mathrm{v})$ acetic acid. The absorbance of reaction products was measured at $410 \mathrm{~nm}$. One unit of enzyme activity was defined as $1 \mu \mathrm{mol}$ of $p$-nitroanilide released per minute, using a molar extinction coefficient of 8800 $\mathrm{cm}^{-1} \mathrm{M}^{-1}$.

Chymotrypsin activity (EC 3.4.21.1) was measured according to continuous method reported by Hummel (1959), and previously used on crabs (Galgani \& Nagayama, 1986), using $630 \mu \mathrm{L}$ BTEE $(0.56 \mathrm{mM} \mathrm{N}-$ benzoyl-L-tyrosine-ethyl ester) dissolved in a buffer of $0.12 \mathrm{M}$ Tris- $\mathrm{HCl}$ with $20 \mathrm{mM} \mathrm{CaCl}_{2} \mathrm{pH} 8.1$ as substrate, $70 \mu \mathrm{L}$ of gastric juices and absorbance of reaction products on final volume reaction $(700 \mu \mathrm{L})$ was measured at $256 \mathrm{~nm}$. One unit of activity was defined as $1 \mu \mathrm{mol}$ of nitroanilide released per minute, using a molar extinction coefficient of $964 \mathrm{~cm}^{-1} \mathrm{M}^{-1}$.

Leucine aminopeptidase (LAP, EC 3.4.11.1) activity was measured using $1.2 \mathrm{mM}$ L-leucine- $p$ nitroanilide dissolved in $50 \mathrm{mM}$ Tris- $\mathrm{HCl} \mathrm{pH} 8.0$ as a substrate, as suggested by Appel (1974). Then, $80 \mu \mathrm{L}$ of gastric juices were added to the substrate and posteriorly stopped enzyme reaction with $200 \mu \mathrm{L}$ of $30 \%(w / v)$ acetic acid. The absorbance of reaction products was measured at $405 \mathrm{~nm}$. One unit of enzyme activity was defined as $1 \mu \mathrm{mol}$ of $p$-nitroanilide released per minute, using a molar extinction coefficient of 8.2 $\mathrm{cm}^{-1} \mathrm{M}^{-1}$.

Collagenase activity (EC 3.4.24.7) was measured according to the method reported by García-Carreño et al. (1994) for marine decapod. Briefly, collagen from bovine Achilles tendon $\left(4.8 \mathrm{mg} \mathrm{mL}^{-1}\right)$ as substrate was suspended in $0.1 \mathrm{M}$ tris(hydroxymethyl)-methyl-2aminoethanesulfonic acid (TES) buffer with $0.35 \mathrm{mM}$ $\mathrm{CaCl}_{2} \mathrm{pH}$ 7.5. The reaction was initiated by adding 25 $\mu \mathrm{L}$ of the enzyme preparation to $1.25 \mathrm{~mL}$ of the substrate solution. Five hours later, the reaction mixture was centrifuged at $4000 \mathrm{~g}$ for $5 \mathrm{~min}$. Then, a $200 \mu \mathrm{L}$ sample of supernatant was transferred to test tubes with $500 \mu \mathrm{L}$ of $1.5 \%$ ninhydrin solution. The mixture was incubated at $100^{\circ} \mathrm{C}$ for $15 \mathrm{~min}$ and then cooled to room temperature, and $2.5 \mathrm{~mL}$ of $50 \%$ ethanol was added with mixing. Then, the absorbance was recorded at 600 $\mathrm{nm}$. One unit of collagenase activity was defined as the amount of enzyme required to cause an increase of 0.1 absorbances per minute.

For all enzyme assays, previous tests were performed to evaluate a suitable reaction time where the rate of product formation was linear. $\mathrm{pH}$ values considerate to evaluate the activity of different specific proteases were chosen according to standard methods previously reported.

The specific activity in gastric juices was determined using the following formula: Activity units $(\mathrm{U} / \mathrm{mg}$ protein $)=[(\Delta \mathrm{Abs} \times \mathrm{mL}$ reactions mix $\times$ dilution factor) / (MEC $\times$ time $(\mathrm{min}) \times \mathrm{mL}$ extract volume $\times \mathrm{mg}$ soluble protein)]; where $\Delta \mathrm{Abs}$ represents the increased absorbance at a specific wavelength, and MEC are the theoretical molar extinction coefficients for the reaction product.

\section{Effect of pH and temperature on proteolytic activity and thermal stability of proteases}

The effect of $\mathrm{pH}$ and temperature to maximize protease activity in gastric juices from both crustacean species was evaluated. The effect of $\mathrm{pH}$ ranging from 2 to 11 on proteases was evaluated using a universal buffer (Stauffer, 1989), which contained similar volume of 25 $\mathrm{mM}$ acetic acid, $25 \mathrm{mM}$ phosphoric acid and $25 \mathrm{mM}$ boric acid, and $\mathrm{pH}$ adjusted with $25 \mathrm{mM}$ sodium hydroxide; $2 \%$ azocasein was used as protein substrate for the assessment at a pH range of 6 to 11. Separately, $0.5 \%$ hemoglobin was used as a substrate for acid proteases at a $\mathrm{pH}$ range from 2 to 5 . Assay conditions were used as described above.

To determine the effect of temperature on protease activity, gastric juices from both species were incubated separately at different reaction temperatures following the standard protocol described above, at 5, $10,2030,40,50,60$ and $70^{\circ} \mathrm{C}, \mathrm{pH} 9.0$. For the thermal stability of enzyme activity on gastric juices, aliquots were previously incubated at different temperatures (5, $15,30,45$ and $60^{\circ} \mathrm{C}$ ) for $0,5,10,20,40,60$ and $90 \mathrm{~min}$ prior to the enzyme reaction assays. Then, the residual proteolytic activity of gastric juices was measured using $2 \%$ azocasein as substrate at $37^{\circ} \mathrm{C}$ and $\mathrm{pH}$ of 9.0 , as described above. Residual enzyme activity was calculated as a percentage (\%) of peak activity measured at time zero with no incubation. 


\section{Effect of inhibitors}

The protease classes present in the gastric juices were evaluated by incubating the enzymatic reaction mixtures with different mixtures of specific inhibitors. Different concentrations of protease inhibitors were used according to recommendations of García-Carreño (1992) and Alarcón et al. (1998). Thus, $0.25 \mathrm{mM}$ type II-S soybean trypsin inhibitor (SBTI) was dissolved in distilled water and $0.1 \mathrm{M}$ phenylmethylsulfonyl fluoride (PMSF) was dissolved in ethanol both were used separately to inhibit serine proteases. To inhibit chymotrypsin activity, $5 \mathrm{mM} \mathrm{N} \alpha$-p-tosyl-L-phenylalanine chloromethyl ketone (TPCK) dissolved in ethanol was used. To inhibit metalloprotease activity, $0.5 \mathrm{M}$ ethylenediaminetetraacetic acid (EDTA) disodium salt dissolved in distilled water was used. Finally, to inhibit aspartic protease activity, $29 \mathrm{mM}$ Pepstatin A dissolved in dimethyl sulfoxide (DMSO) was used. Briefly, $20 \mu \mathrm{L}$ of gastric juice was mixed with $0.5 \mathrm{~mL} 50 \mathrm{mM}$ Tris- $\mathrm{HCl}, 10 \mathrm{mM} \mathrm{CaCl}_{2}$ buffer $\mathrm{pH}$ 9 and $10 \mu \mathrm{L}$ of a specific inhibitor, and incubated for $60 \mathrm{~min}$ at $37^{\circ} \mathrm{C}$. Then, the mixture was assayed for alkaline protease (for SBTI, PMSF, TPCK, and EDTA) or aspartic protease (for Pepstatin A) activities using $2 \%$ azocasein or $2 \%$ hemoglobin, respectively, as described above. The percent relative inhibition or residual activity was reported as the loss of enzyme activity compared to a control with no inhibitor (as $100 \%$ ). All assays were run in triplicate samples.

\section{Statistical analysis}

The results of all assays are reported as the mean \pm standard deviation (SD). The enzyme activity for specific proteases and the effect of specific inhibitors were analyzed between species using a Student's $t$-test. The effect of $\mathrm{pH}$ and temperature on the alkaline proteolytic activity for both crustacean species was analyzed separately using a one-way ANOVA. Percent data from inhibition assays were previously transformed to arcsin of square-root from variable to comply with the assumptions of normality and homos- cedasticity (Zar, 1996). When significant differences were found between mean values, a Tukey's multiple comparison test was performed. Differences were considered significant at $P<0.05$. All statistical analyses were performed using the graphical and statistical program SigmaPlot, Version 11.0 (Erkrath, Germany).

\section{RESULTS}

\section{pH, soluble protein, and specific proteolytic activities}

Non-significant differences $(P=0.057)$ were detected in the slightly acid $\mathrm{pH}$ values measured in gastric juices of $L$. santolla $(6.0 \pm 0.06)$ and C. edwardsii (5.9 \pm 0.06$)$. The amount of soluble protein measured in the gastric juices $\left(32.2 \pm 2.4\right.$ and $31.0 \pm 5.9 \mathrm{mg} \mathrm{mL}^{-1}$ for $L$. santolla and $C$. edwardsii, respectively) showed no statistical differences $(P=0.731)$ between species.

Alkaline and acid protease activity was significantly lower $(P=0.025$ and $P<0.001$, respectively) in $L$. santolla relative to $C$. edwardsii. Trypsin activity showed non-significant differences $(P=0.315)$ between species. However, collagenase activity in $L$. santolla was significantly lower $(P=0.03)$ than in $C$. edwardsii. Conversely, chymotrypsin and LAP activities were significantly higher $(P=0.007$ and $P=0.002$, respectively) in $L$. santolla than in C. edwardsii (Table 1).

\section{pH and temperature effect on total proteolytic activity and thermal stability of proteases}

The effect of $\mathrm{pH}$ on the proteolytic activity of gastric juices of $L$. santolla and $C$. edwardsii, is shown in Figure 1. The gastric juices of L. santolla (Fig. 1a) showed a high variability of proteolytic activity (34-44 $\mathrm{U} \mathrm{mg}$ protein $\left.^{-1}\right)$ at a $\mathrm{pH}$ range of 6 to 11 , with nonsignificant differences $(P=0.135)$ between values. However, a significant reduction $(P<0.001)$ of proteolytic activity (from 3.8 to $0 \mathrm{U}$ mg protein ${ }^{-1}$ ) was observed concomitant to the drop of $\mathrm{pH}$ in the reaction mixture, from 5 to 2 (Fig. 1a).

Table 1. Protease activity and soluble protein in the gastric juice of adults of southern king crab $L$. santolla and Chilean rocky crab C. edwardsii. Values (mean $\pm \mathrm{SD})$ in the same row with different superscript are significantly different $(P<$ $0.05)$.

\begin{tabular}{|c|c|c|}
\hline Proteases & L. santolla & C. edwardsii \\
\hline Alkaline proteases $\left(\mathrm{U}\right.$ mg protein $\left.^{-1}\right)$ & $15.1 \pm 0.33^{\mathrm{b}}$ & $20.7 \pm 2.77^{\mathrm{a}}$ \\
\hline Acid proteases (U mg protein $\left.{ }^{-1}\right)$ & $25.9 \pm 0.91^{\mathrm{b}}$ & $35.9 \pm 0.79^{\mathrm{a}}$ \\
\hline Trypsin $\left(\mathrm{mU} \mathrm{mg} \mathrm{protein}{ }^{-1}\right)$ & $0.45 \pm 0.06$ & $0.52 \pm 0.09$ \\
\hline Chymotrypsin (mU mg protein $\left.{ }^{-1}\right)$ & $0.007 \pm 0.001^{\mathrm{a}}$ & $0.003 \pm 0.001^{b}$ \\
\hline Collagenase $\left(\mathrm{U}\right.$ mg protein $\left.{ }^{-1}\right)$ & $0.045 \pm 0.002^{\mathrm{b}}$ & $0.052 \pm 0.01^{\mathrm{a}}$ \\
\hline Leucine-aminopeptidase, $\left(\mathrm{mU} \mathrm{mg}\right.$ protein $\left.^{-1}\right)$ & $0.07 \pm 0.01^{\mathrm{a}}$ & $0.02 \pm 0.01^{\mathrm{b}}$ \\
\hline Soluble protein $\left(\mathrm{mg}\right.$ protein $\left.\mathrm{mL}^{-1}\right)$ & $32.2 \pm 2.4$ & $31.0 \pm 5.9$ \\
\hline
\end{tabular}



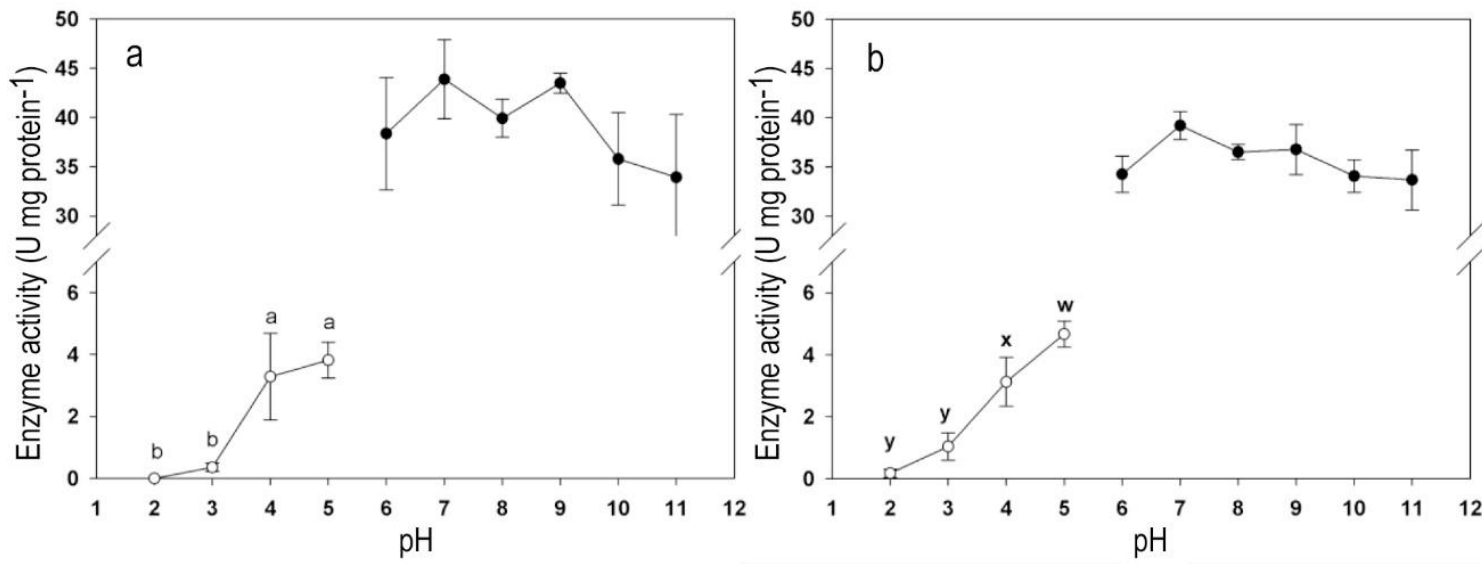

Figure 1. Effect of $\mathrm{pH}$ on specific enzyme activity from the gastric juices of adults of a) southern king crab L. santolla, and b) Chilean rocky crab C. edwardsii. The substrates used were hemoglobin (pH 2-5) and casein (pH 6-11). Values (mean \pm SD) with differents letter are significantly different $(P<0.05)$.

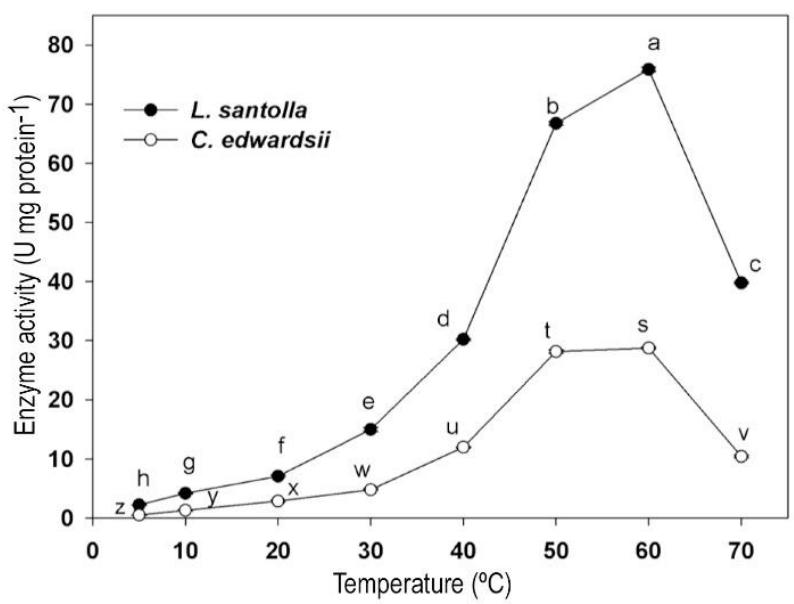

Figure 2. Effect of temperature on specific enzyme activity in the gastric juices of adults of southern king crab L. santolla and Chilean rocky crab C. edwardsii. Values (mean $\pm \mathrm{SD}$ ) with different letters are significantly different $(P<0.05)$.

The gastric juices of $C$. edwardsii showed a range of 34-39 $\mathrm{U} \mathrm{mg}$ protein ${ }^{-1}$ on proteolytic activity at $\mathrm{pH} 6$ to 11 , with non-significant differences between values (Fig. 1b). Similar to L. santolla, a significant reduction of proteolytic activity of the gastric juices of $C$. edwardsii was observed ( $P<0.001$ for both species) at an acid $\mathrm{pH}$ (pH 2 to 5), which was almost nil at pH 2.

The effect of temperature on the total proteolytic activity of gastric juices of $L$. santolla and $C$. edwardsii at $\mathrm{pH} 9$ is shown in Figure 2. A similar trend was observed in both crustacean species for specific enzyme activity at different reaction temperatures, where proteolytic activity increased significantly from 5 to $60^{\circ} \mathrm{C}$. Thus, for both species, the maximum activity was observed at $60^{\circ} \mathrm{C}$; however, $L$. santolla showed a higher proteolytic activity $\left(75.9 \pm 0.4 \mathrm{U} \mathrm{mg} \operatorname{protein}^{-1}\right)$ compared to C. edwardsii $\left(28.8 \pm 0.14 \mathrm{U} \mathrm{mg} \mathrm{protein}^{-1}\right)$. On the other hand, proteolytic activity dropped abruptly to nearly $15 \%$ of the peak activity in both species when the enzymatic reaction was performed at $70^{\circ} \mathrm{C}$.

The thermal stability of the total alkaline proteolytic activity in L. santolla (Fig. 3a) was maintained above $90 \%$ when gastric juices were incubated at $30^{\circ} \mathrm{C}$ for 10 min, with an abrupt subsequent drop of the proteolytic activity; while the total activity was above $80 \%$ when the gastric juice was incubated at $5^{\circ} \mathrm{C}$ for $90 \mathrm{~min}$. For L. santolla, a residual proteolytic activity between 50 and $60 \%$ was observed after incubation at $30^{\circ} \mathrm{C}$ and $45^{\circ} \mathrm{C}$ for $90 \mathrm{~min}$ (Fig. 3a).

Moreover, in the case of C. edwardsii, a proteolytic activity $>90 \%$ was maintained (Fig. 3b) when gastric juices were incubated at temperatures as high as $45^{\circ} \mathrm{C}$ for $20 \mathrm{~min}$. Also, the gastric juices of C. edwardsii showed a high proteolytic activity (residual activity $>90 \%$ ) when the gastric juice was incubated at $15^{\circ} \mathrm{C}$ for 90 min, and the activity was $>80 \%$ when gastric juices were incubated at $45^{\circ} \mathrm{C}$ for $60 \mathrm{~min}$. However, a marked loss of activity (residual activity $<20 \%$ ) was observed in both $L$. santolla and C. edwardsii (Figs. 3a-3b) after 10 min when gastric juices were incubated at $60^{\circ} \mathrm{C}$.

\section{Effect of specific inhibitors on total protease activity}

Different specific inhibitors were employed in order to identify the contribution of individual protease classes to the total proteolytic activity of the gastric juice of both crustacean species (Table 2). The total proteolytic activity (at $\mathrm{pH}$ 9) of gastric juices of $L$. santolla and $C$. edwardsii was highly and similarly inhibited by SBTI (64.6\% and 59.8\% inhibition, respectively; $P=0.27$ ) 

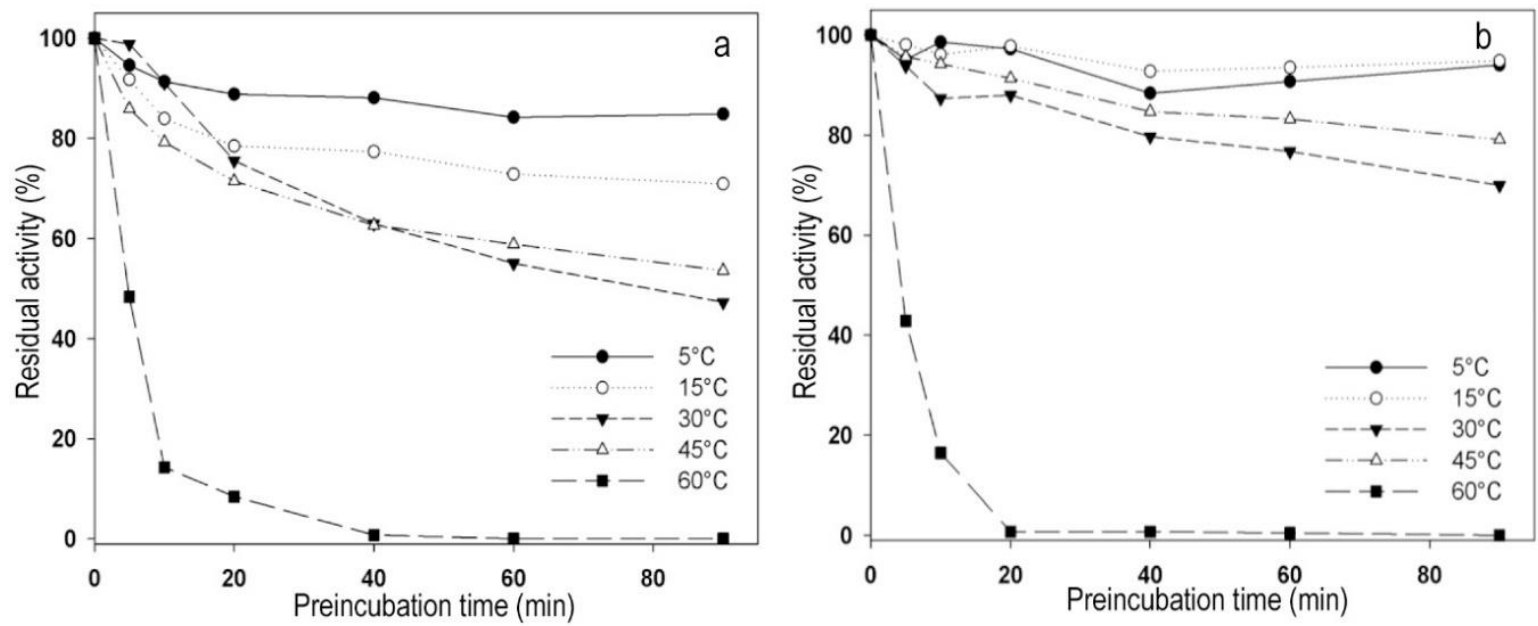

Figure 3. a) Thermostability of total alkaline protease activity from the gastric juice of adults of southern king crab $L$. santolla, and b) Chilean rocky crab C. edwardsii. Activity was normalized to $100 \%$ for maximum activity recorded.

Table 2. Effect of specific inhibitors on total activity of alkaline protease and aspartic protease contained in the gastric juice of adults of southern king crab $L$. santolla and Chilean rocky crab C. edwardsii. Values (mean $\pm \mathrm{SD}$ ) in the same row with different superscripts are significantly different $(P<0.05)$.

\begin{tabular}{lcccc}
\hline \multirow{2}{*}{ Inhibitor } & $\begin{array}{c}\text { Stock concentration } \\
(\mathrm{mM})\end{array}$ & $\begin{array}{c}\text { Concentration in } \\
\text { reaction mixture }(\mathrm{mM})\end{array}$ & \multicolumn{2}{c}{ Percentage of inhibition $(\%)$} \\
\hline Total alkaline protease & & & & \\
SBTI & 0.25 & 0.002 & $64.6 \pm 2.5$ & $59.8 \pm 4.2$ \\
PMSF & 100 & 0.962 & $54.7 \pm 5.5$ & $61.3 \pm 6.9$ \\
TPCK & 5 & 0.048 & $21.1 \pm 0.8^{\mathrm{a}}$ & $13.1 \pm 3.7^{\mathrm{b}}$ \\
EDTA & 500 & 4.850 & $8.9 \pm 2.9^{\mathrm{a}}$ & $2.5 \pm 2.0^{\mathrm{b}}$ \\
Total acid protease & & & & \\
Pepstatin A & 29 & 0.280 & $31.0 \pm 2.2$ & $35.5 \pm 3.0$ \\
\hline
\end{tabular}

and PMSF (54.7\% and 61.3\% inhibition, respectively; $P=0.13)$. On the other hand, TPCK, a specific chymotrypsin inhibitor, reduced proteolytic activity to a significantly higher $(P=0.02)$ extent in the southern king crab $(21.1 \pm 0.8 \%$ inhibition) versus the Chilean rocky crab (13.1 $\pm 3.7 \%$ inhibition). EDTA, a metalloprotease inactivator, achieved a significantly higher $(P=0.003)$ reduction of the proteolytic activity in L. santolla (8.9\% inhibition) versus $C$. edwardsii (2.5\% inhibition). The activity of total acid proteases (at $\mathrm{pH} 3$ ) contained in the gastric juices of $L$. santolla and $C$. edwarsii was similarly inhibited $(31 \%$ and $35.5 \%$ inhibition, respectively; $P>0.05$ ) by Pepstatin A. SBTI, soybean trypsin inhibitor; PMSF, phenylmethylsulfonyl fluoride; TPCK, N-p-tosyl-Lphenylalanine chloromethyl ketone; EDTA, ethylenediaminetetraacetic acid. Values (mean \pm SD) within the same row with different superscript are significantly different $(P<0.05)$.

\section{DISCUSSION}

The use of gastric juices for the biochemical analysis of digestive enzymes is a technique commonly used for medium- and large-sized crustaceans such as crabs (Saborowski et al., 2004, 2006; Díaz-Tenorio et al., 2006; Navarrete del Toro et al., 2006), lobsters (CelisGuerrero et al., 2004; Bibo-Verdugo et al., 2016), and crayfish (Coccia et al., 2011). Compared to the use of tissue homogenates, the utilization of gastric juice entails some advantages, namely: 1) to reduce the presence of soluble non-enzymatic tissue protein on enzyme sources, leads to a more accurate estimation from the specific enzyme activity $\left(\mathrm{U} \mathrm{mg}\right.$ of protein $^{-1}$ ), 2) prevent the death of the study specimen, hence allowing to perform sequential studies using the same specimen under various experimental conditions (e.g., temperature, food types, molt stages, etc.). 
Crustacean gastric juices are a cocktail of protease zymogens synthesized by F-cells in the digestive gland (Ceccaldi, 1989), which are then secreted into the lumen of tubules along with other digestive enzymes (e.g., esterases, lipases, amylases, glycosidases, chitinases, and other) into the gut cavity. Thus, in the present work, we used gastric juices to determine the trypsin-, chymotrypsin-, collagenase- and leucine-aminopeptidase activities, in addition to the total acid and alkaline proteolytic activity, in the southern king crab and the Chilean rock crab using alive and fasted specimens.

A study on the partial biochemical characterization of digestive enzymes in $L$. santolla during different ontogenic stages using semi-quantitative and quantitative techniques has been previously reported by Saborowski et al. (2006). However, the present study supplements the enzymatic biochemical characterization by evaluating the effect of different physical (temperature) and chemical $(\mathrm{pH})$ factors, as well as by determining the activity of other protease classes and the effect of specific enzyme inhibitors on the digestive proteolytic activity in L. santolla and C. edwardsii. Moreover, in the case of the C. edwardsii, this is the first report related to the biochemical characterization of its gastric proteases.

Trypsin is a ubiquitous protease in decapod crustaceans (Muhlia-Almazán et al., 2008). This study found similar trypsin activities in both species. In $L$. santolla, high trypsin activity levels have been reported in the gastric juice of adult crabs, but not for eggs and larval stages (Saborowski et al., 2006). In this research, chymotrypsin activity was detected in both species, with lower levels in $C$. edwarsii relative to $L$. santolla. In other studies with crustaceans, nil chymotrypsin activity has been reported. For instance, lithodid species such as Lithodes aequispinus, Paralithodes camtschaticus, $P$. brevipes, $P$. neolithodes and Nipponensis multispina, chymotrypsin activity was not detected using succinyl-p-nitroanilide as substrate (Galgani \& Nagayama, 1987). In Cancer pagurus, a high chymotrypsin activity was detected on gastric juice, produced by a single isoform (Saborowski et al., 2004). In another study, Saborowski et al., (2006) detected chymotrypsin-type activity in eggs, larvae, juveniles and adults of $L$. santolla using $\mathrm{N}$-succinylala-ala-pro-phe $p$-nitroanilide as a substrate, but not when used N-glutaryl-phenylalanine-2-naphthylamide. Therefore, the absence of activity of a digestive enzyme in an analysis, rather than the lack of production by the organism, could be due to both, the incompatibility with the utilized substrate, and to the particular digestive enzyme analyzed (Saborowski et al., 2006; Pereda et al., 2009); another factor influencing the low activity of a specific class of proteases, could be the lack of biochemical and/or physical conditions suitable for the enzymatic kinetics.

Collagenolytic activity was observed in both crustacean species studied, being significantly higher in C. edwardsii than in L. santolla. Collagenases are enzymes belonging to the serine-protease group, and this kind of activity has been reported in predator and scavenger crustaceans, including lithodid crabs (Galgani \& Nagayama, 1987) that preying on organisms in which collagen is the main connective tissue component (Díaz-Tenorio et al., 2006). Both C. edwardsii and L. santolla are opportunistic omnivorous predators. In this regard, $C$. edwarsii is carnivorous to a greater extent (Tapia et al., 2008) relative to L. santolla, as coralline algae, echinoderms, mollusks, and other invertebrates have been found in the gut content of the latter (Vinuesa et al., 2013). This characteristic could be related to the higher collagenolytic, alkaline an acidic proteolytic activity observed in C. edwardsii relative to the proteolytic activity detected in $L$. santolla. On the other hand, collagenases of cold-water invertebrates, such as lithodid crabs (Klimova \& Chebotarev, 2000; Semenova et al., 2008), have been widely studied due to their biotechnological importance for food, cosmetics, and pharmaceutical industries, among others.

In gastric juices and midgut-gland extracts of the red claw crayfish Cherax quadricarinatus, Figuereido et al. (2001) detected leucine aminopeptidase activity, as the pH (7.0) was optimal for this enzyme. In L. santolla, Saborowski et al. (2004) recorded alanineaminopeptidase activity from the egg to the adult stages. Similarly, aminopeptidase activity has been reported for various ontogenic stages of crustaceans such as Pleuroncodes planipes and Pacifastacus astacus (García-Carreño et al., 1994), Munida spp. (Rossano et al., 2011), Farfantepenaeus subtilis (Buarque et al., 2010), and Maja brachydactyla (Andrés et al., 2010). The presence of leucine aminopeptidase activity in both crustacean species evaluated in this research indicates that these organisms are adapted to digest peptides either in the diet or derived from protein digestion, because while trypsin and chymotrypsin (proteinases) cleave the inner peptide bonds, aminopeptidases (peptidases) complete protein digestion by making it more efficient (Figuereido et al., 2001).

The $\mathrm{pH}$ values measured in the gastric juices of $L$. santolla (6.0) and C. edwardsii (5.9) are similar to the slightly acid values reported for other crustacean species such as C. pagurus, 5.8 (Saborowski et al., 2004), Cherax quadricarinatus, 5.8 (Figuereido et al., 2001), Callinectes arcuatus, 6.1; Panulirus interruptus, 
6.0 (Navarrete del Toro et al., 2006) and penaeid shrimps, 5.7 (Navarrete del Toro et al., 2011).

For the species studied in this work, proteolytic activity was observed in both, alkaline and acid $\mathrm{pH}$. In addition, no significant differences were observed in the total proteolytic activity evaluated over a wide $\mathrm{pH}$ range (6 to 11). Highest total proteolytic activities at a $\mathrm{pH}$ range of 5 to 8 have been reported for other crustacean species (Galgani \& Nagayama 1987; Figuereido et al., 2001; Díaz-Tenorio et al., 2006; Saborowski et al., 2006; Figueiredo \&Anderson, 2009), as was also reported for $C$. pagurus (Saborowski et al., 2004). In other lithodid crab species, the optimal $\mathrm{pH}$ for proteolytic activity lied within a narrow $\mathrm{pH}$ range of 7 to 7.8 (Galgani \& Nagayama, 1987). Nevertheless, having proteolytic activity in a wide $\mathrm{pH}$ range gives an organism a greater catalytic potential to digest more efficiently food nutrients under different physiological conditions $(\mathrm{pH})$ in the gastric chamber. As observed, in the present study we have not found a match between $\mathrm{pH}$ of gastric juices and $\mathrm{pH}$-profile of proteolytic activity, which is in agreement with previous reports (Figueiredo et al., 2001; Celis-Guerrero et al., 2004; Saborowski et al., 2004). Moreover, different $\mathrm{pH}$ values were used to measure trypsin, chymotrypsin, LAP and collagenase activities which also does not correspond to $\mathrm{pH}$ measured in gastric juices for both species, but were chosen according to reports of standard methods (García-Carreño et al., 1994); however, we suggest to realize further studies to evaluate the effect of $\mathrm{pH}$ as well as $\mathrm{pH}$-stability of different specific proteases present in gastric juices of C. edwardsii and L. santolla.

For both crustacean species studied, the highest proteolytic activity was observed at $60^{\circ} \mathrm{C}$. Optimal temperatures reported for other lithodid and brachyuran crabs range from 45 to $55^{\circ} \mathrm{C}$ (Galgani \& Nagayama, 1987; Saborowski et al., 2004). However, these "optimal" temperatures observed in vitro are far above of the maximum temperatures tolerated by $L$. santolla and C. edwarsii. According to Calcagno et al. (2005), $L$. santolla juveniles are well adapted to subarctic marine environments $\left(5-10^{\circ} \mathrm{C}\right)$, but high mortality rates have been observed at 12 to $15^{\circ} \mathrm{C}$, despite the fact that these temperatures lead to accelerated growth and maturation rates.

Results of the thermal stability of proteases present in the gastric juices reveal a lower thermal stability for L. santolla relative to C. edwarsii. For L. santolla, $80 \%$ and $50 \%$ of the total proteolytic activity remained after incubating the gastric juices at 15 and $30^{\circ} \mathrm{C}$, respectively, prior to the enzymatic reaction. In contrast, for C. edwardsii over 70 and $90 \%$ of the total proteolytic activity was recorded at the same incubation conditions. The proteolytic activity of $C$. edwarsii disappeared after incubating the gastric juices at $60^{\circ} \mathrm{C}$ for $20 \mathrm{~min}$. Similar results were observed for coldwater crustaceans such as C. pagurus (Saborowski et al., 2004), Homarus americanus and Homarus gammarus (Rojo et al., 2013), where proteases were almost deactivated after incubation at $60^{\circ} \mathrm{C}$ for $20 \mathrm{~min}$. Proteases from psychrophilic organisms such as $C$. edwardsii and L. santolla are thermolabile due to their limited structural stability (Gerday et al., 2000; Rojo et al., 2013), which is related to the weak hydrophobic interactions at the inner protein structure (Oh et al., 2000). In contrast, proteases from the gastric juices of crustaceans that inhabit in tropical waters exhibit high thermostability (García-Carreño \& Haard, 1993; Oh et al., 2000). Thus, the proteolytic activity of both studied crustaceans species was deactivated using even mild temperatures $\left(60^{\circ} \mathrm{C}\right)$. This feature is relevant for potential technological applications (Rossano et al., 2011), mainly in food processing industry (e.g., manufacture of cheese, roe processing, recovery of pigments in seafood, among others).

In the present study, specific inhibitors were used to characterize the protease classes in the gastric juices analyzed. Serine proteases (mainly trypsin-like and chymotrypsin-like enzymes) result important for the protein digestion process in both studied species. Approximately, 55 and $60 \%$ of proteolytic activity from C. edwardsii and L. santolla, respectively, was inhibited when PMSF was used. García-Carreño \& Haard (1993), and Buarque et al. (2010), also reported an inhibition of more than $50 \%$ on proteolytic activity when PMSF was used in different species of omnivore decapod crustaceans. Likewise, SBTI led to $60 \%$ of total proteolytic activity in the digestive juices of $L$. santolla and C. edwardsii. Both SBTI and PMSF are serine-protease inhibitors, but SBTI is more specific for trypsin-like enzymes. Therefore, trypsin represents the main serine protease contained in the analyzed gastric juices, which is a feature shared with other decapod species (Celis-Guerrero et al., 2004; Perera et al., 2008; Coccia et al., 2011). Chymotrypsin participated to a lesser extent in protein digestion, since the inhibitor TPCK led to an $18 \%$ reduction of total proteolytic activity in both species. However, the inhibition of proteases using TPCK has been inefficient in other crustacean species (García-Carreño \& Haard, 1993; García-Carreño et al., 1994; Fernández-Gimenez et al., 2002; Perera et al., 2008; Buarque et al., 2010), suggesting that the use of other specific chymotrypsin inhibitors (e.g., chymostatin) should be further evaluated to corroborate the findings obtained in this research. Also, the sum of inhibition caused by SBTI and TPCK not necessarily are similar with those values 
found for PMSF inhibition, since TPCK also could to inhibit some cysteine proteases (Oppert et al., 2003) contained in gastric juices. With regard to the inhibition of metalloproteases, such as leucine aminopeptidase, EDTA led to a $2.5 \%$ and $8.9 \%$ inhibition of proteolytic activity in the gastric juice of $C$. edwardsii and $L$. santolla, respectively. Values of metalloproteases contributing to total alkaline proteolytic activity for both species in the present study are low when compared to those reported for other crustacean species such as P. planipes and P. astacus (García-Carreño \& Haard, 1993), for which inhibitions between $18 \%$ and $32 \%$ of the total proteolytic activity have been reported. However, to date and compared with other proteases, studies on crustaceans where inhibition of metalloproteases has been reported are scarce.

In crustaceans, not all the digestive proteolytic activity is performed only by serine proteases alone. Activity of aspartic and cysteine proteases has been reported in gastric juices and extracts of the midgut gland of decapods, which act in an acid-to-neutral $\mathrm{pH}$ range and play an important role in the digestive process of protein (Hu \& Leung, 2007; Andrés et al., 2010; Rojo et al., 2010, 2013). In species such as $H$. americanus (Laycock et al., 1989), Crangon crangon and Crangon allmani (Teschke \& Saborowski, 2005), cysteine proteases such as cathepsins can even account for more than $60 \%$ of the total proteolytic activity. Also, aspartic proteases have been detected in gastric juices of $P$. interruptus, $C$. pagurus, $C$. arcuatus and Callinectes bellicosus (Navarrete del Toro et al., 2006), H. gammarus and H. americanus (Rojo et al., 2013), as well as in enzyme extracts of Munida (D'Ambrosio et $a l ., 2003)$. In the present study, acid proteases activity was measured at $\mathrm{pH} 3.0$ to ensure that such activity mainly comes from aspartic proteases. In some crustacean species, serine proteases still remain actives at a $\mathrm{pH}$ close to 5 (Saborowski et al., 2004; BiboVerdugo et al., 2015). For both crab species evaluated in this study, Pepstatin A (a specific inhibitor of aspartic proteases) inhibited around $30 \%$ of the acid proteolytic activity ( $\mathrm{pH} 3$ ) in gastric juices. The contribution of aspartic proteases to acid proteolytic activity is variable among crustaceans, since for $P$. planipes and $P$. astacus these contribute with $9 \%$ and $15 \%$ at $\mathrm{pH} 4.5$, respectively (García-Carreño et al., 1993); in contrast, in H. gammarus and P. interruptus these proteases account for more than $70 \%$ of the activity at pH 3 (Navarrete del Toro et al., 2006).

Data on the activity of total alkaline and acid proteases from the gastric juice of $C$. edwardsii and $L$. santolla confirm the importance of these enzymes in the digestive process of the organisms studied. Our results regarding inhibition studies revealed that the proteolytic activity of the gastric juice of $C$. edwardsii and $L$. santolla is largely related to the presence of serin and aspartic proteases. Peak protease activities in both organisms studied were recorded at $\mathrm{pH}$ 6. Moreover, the thermal stability of gastric proteases of $C$. edwarsii was higher than the one exhibited by proteases of $L$. santolla. However, proteases of gastric juices from $C$. edwardsii and $L$. santolla result in thermolabile respect to proteases from mesophilic animals (Rojo et al., 2013). This behavior points to the potential application of gastric proteases as a biotechnological aid in processes that require mild temperatures to deactivate proteolytic activity. In order to explore specific biotechnological/aquaculture applications of proteases from C. edwardsii and L. santolla gastric juices, further studies about the isolation and individual characterization of collagenases, serine, and aspartic proteases are highly recommended.

\section{ACKNOWLEDGMENTS}

This study was supported by the Dirección de Investigación y Desarrollo (DID) from Universidad Austral de Chile (UACh), Project No. S-2012-29. The authors thank María Elena Sánchez Salazar for her editorial work in English.

\section{REFERENCES}

Alarcón, F.J., M. Díaz, F.J. Moyano \& E. Abellán. 1998. Characterization and functional properties of digestive proteases in two sparids; gilthead seabream (Sparus aurata) and common dentex (Dentex dentex). Fish Physiol. Biochem., 19: 257-267.

Andrés, M., E. Gisbert, M. Díaz, F.J. Moyano, A. Estévez \& G. Rotllant. 2010. Ontogenetic changes in digestive enzymatic capacities of the spider crab, Maja brachydactyla (Decapoda: Majidae). J. Exp. Mar. Biol. Ecol., 389: 75-84.

Appel, W. 1974. Leucine aminopeptidase determination with L-leucinamide as substrate. In: H.U. Bergmeyer (ed.). Methods of enzymatic analysis. Academics Press, New York, pp. 954-958.

Berge, G.M. \& A. Woll. 2006. Feeding saithe fillet or a formulated moist feed to the brown crab Cancer pagurus: effects on yield, composition and sensory quality of medium filled captured crabs. Aquaculture, 258: 496-502.

Bibo-Verdugo, B., L. Rojo-Arreola, M.A. Navarrete del Toro \& F. García-Carreño. 2015. A chymotrypsin from the digestive tract of California spiny lobster, Panulirus interruptus: Purification and biochemical characterization. Mar. Biotechnol., 17(4): 416-427. 
Bibo-Verdugo, B., A.J. O’Donoghue, L. Rojo-Arreola, C.S. Craik \& F. García-Carreño. 2016. Complementary proteomic and biochemical analysis of peptidases in lobster gastric juice uncovers the functional role of individual enzymes in food digestion. Mar. Biotechnol., 18: 201-214.

Bradford, M. 1976. A rapid and sensitive method for the cuantitation of microgram quantities of protein utilizing the principle of dye binding. Anal. Biochem., 72: 248-254.

Buarque, D.S., P.F. Castro, F.M.S. Santos, I.P.G. Amaral, S.M. Oliveira, K.B. Alves, L.B. Carvalho \& R.S. Bezerra. 2010. Digestive proteinases and peptidases in the hepatopancreas of the southern brown shrimp (Farfantepenaeus subtilis) in two sub-adult stages. Aquacult. Nutr., 16: 359-369.

Buchholz, F. \& R.A.H. Vetter. 1993. Enzyme kinetics in cold water: characteristics of N-acetyl- $\beta$-D-glucosaminidase activity in the Antartic krill, Euphausia superba, compared with other crustacean species. J. Comp. Physiol. B, 163: 28-37.

Calcagno, J.A., K. Anger, G.A. Lovrich, S. Thatje \& A. Kaffenberger. 2004. Larval development of the subantarctic king crabs Lithodes santolla and Paralomis granulosa reared in the laboratory. Helgoland Mar. Res., 58: 11-14.

Calcagno, J.A., G.A. Lovrich, S. Thatje, U. Nettelmann \& K. Anger. 2005. First-year growth in the lithodids Lithodes santolla and Paralomis granulosa reared at different temperatures. J. Sea Res., 54: 221-230.

Ceccaldi, H.J. 1989. Anatomy and physiology of digestive tract of crustaceans decapods reared in aquaculture. Advan. Trop. Aquacult. AQUA-COP. IFREMER Actes de Colloque, pp. 243-259.

Celis-Guerrero, L.E., F.L. García-Carreño \& M.A. Navarrete del Toro. 2004. Characterization of proteases in the digestive system of spiny lobster (Panulirus interruptus). Mar. Biotechnol., 6: 262-269.

Coccia, E., E. Varricchio \& M. Paolucci. 2011. Digestive enzymes in the crayfish Cherax albidus: polymorphism and partial characterization. Int. J. Zool., 2011: 1-9.

Comoglio, L., J. Goldsmit \& O. Amin. 2008. Starvation effects on physiological parameters and biochemical composition of the hepatopancreas of the southern king crab Lithodes santolla (Molina, 1782). Rev. Biol. Mar. Oceanogr., 43: 345-353.

Cuzon, G., J. Guillaume \& C. Cahu. 1994. Composition, preparation and utilization of feeds for crustacean. Aquaculture, 124: 253-267.

D'Ambrosio, A., R. Rossano, N. Ungaro \& P. Riccio. 2003. Proteolytic and milk clotting activities in extracts obtained from the crustaceans Munida. J. Mol. Catal. B-Enzym., 22: 145-150.
Díaz-Tenorio, L.M., F.L. García-Carreño \& M.A. Navarrete del Toro. 2006. Characterization and comparison of digestive proteinases of the Cortez swimming crab, Callinectes bellicosus, and the arched swimming crab, Callinectes arcuatus. Invertebr. Biol., 125: 125-135.

Erlanger, B., N. Kokowsky \& W. Cohen. 1961. The preparation and properties of two new chromogenic substrates of trypsin. Arch. Biochem. Biophys., 95: 271-278.

Fernández-Gimenez, A.V. 2013. Digestive physiology of three species of decapod crustaceans of Argentina. J. Shellfish Res., 32: 767-777.

Fernández-Gimenez, A.V., F.L. García-Carreño, M.A. Navarrete del Toro \& J.L. Fenucci. 2002. Digestive proteinases of Artemesia longinaris (Decapoda, Penaeidae) and relationship with molting. Comp. Biochem. Physiol. B., 132: 593-598.

Figueiredo, M.S.R.B. \& A.J. Anderson. 2009. Digestive enzyme spectra in crustacean decapods (Paleomonidae, Portunidae, and Penaeidae) feeding in the natural habitat. Aquacult. Res., 40: 282-291.

Figuereido, M.S.R.B., J.A. Kricker \& A.J. Anderson. 2001. Digestive enzyme activities in the alimentary tract of red claw crayfish, Cherax quadricarinatus (Decapoda: Parastacidae). J. Crustacean Biol., 21: 334-344.

Freese, D., T. Kreibich \& B. Niehoff. 2012. Characteristics of digestive enzymes of calanoid copepod species from different latitudes in relation to temperature, $\mathrm{pH}$, and food. Comp. Biochem. Physiol. B, 162: 66-72.

Galgani, F. \& F. Nagayama. 1987. Characteristic of digestive proteolysis of the crabs Portunus trituberculatus, Portunus sanguinolentus and Charybdis japonica. Bull. Jpn. Soc. Sci. Fish., 52: 2183-2188.

Galgani, F. \& F. Nagayama. 1987. Digestive proteinases in five species of Lithodidae (Crustacea, Decapoda). Comp. Biochem. Physiol. B, 87: 103-107.

García-Carreño, F.L. 1992. Protease inhibition in theory and practice. Biotechnol. Educ., 3(4): 145-150.

García-Carreño, F.L. \& N.F. Haard. 1993. Characterization of proteinase classes in langostilla (Pleuroncodes planipes) and crayfish (Pacifastacus astacus) extracts. J. Food Biochem., 17: 97-113.

García-Carreño, F.L., M.P. Hernández-Cortés \& N.F. Haard. 1994. Enzymes with peptidase and proteinase activity from the digestive systems of a freshwater and marine decapod. J. Agr. Food Chem., 42: 1456-1461.

Gerday, C., M. Aittaleb, M. Bentahir, J.P. Chessa, P. Claverie, T. Collins, S. D’Amico, J. Dumont, G. Garsoux, D. Georlette, A. Hoyoux, T. Lonhienne, 
M.A. Meuwis \& G. Feller. 2000. Cold-adapted enzymes: from fundamentals to biotechnology. Trends Biotechnol., 18: 103-107.

Hu, K.J. \& P.C. Leung. 2007. Food digestion by cathepsin $\mathrm{L}$ and digestion-related rapid cell differentiation in shrimp hepatopancreas. Comp. Biochem. Physiol. B, 146: 69-80.

Hummel, B.C. 1959. A modified spectrophotometric determination of chymotrypsin, trypsin, and thrombin. Can. J. Biochem. Physiol., 37: 1393-1399.

James, P., R. Vasilyev, S. Siikavuopio, N. Kovatcheva, T.A. Samuelsen, H. Mundheim \& M. Carlehög. 2013. The effects of varying the percentage of herring versus salmon protein in manufactured diets on the survival, meat content, hepatosomatic index and meat sensory quality of adult red king crab Paralithodes camtschaticus held in captivity. Aquaculture, 416-417: 390-395.

Klimova, O.A. \& V.Y. Chebotarev. 2000. Collagenolytic protease preparations from invertebrates: biochemical aspects of medical and cosmetological applications. Bull. Exp. Biol. Med., 130(7): 671-675.

Laycock, M.V., T. Hirama, S. Hasnain, D. Watson \& A. Storer. 1989. Purification and characterization of a digestive cysteine proteinase from the American lobster (Homarus americanus). Biochem. J., 263: 439444.

Lemos, D., J.M. Ezquerra \& F.L. Garcia-Carreño. 2000. Protein digestion in penaeid shrimp: digestive proteinases, proteinase inhibitors and feed digestibility. Aquaculture, 186: 89-105.

Lindner, P., A. Eshel, S. Kolkovski, A. Tandler \& S. Harpaz. 1995. Proteolysis by juvenile sea bass (Dicentrarchus labrax) gastrointestinal enzyme as a method for the evaluation of feed proteins. Fish Physiol. Biochem., 14: 399-407.

Lovrich, G.A. \& F. Tapella. 2014. Southern king crab. In: B.G. Stevens (ed.). King crabs of the world: biology and fisheries management. CRC Press, Florida, pp. 449-484.

Márquez, L., M. Øverland, S. Martínez-Llorens, T. Morken \& F.J. Moyano. 2013. Use of a gastrointestinal model to assess potential amino acid bioavailability in the diet for rainbow trout (Oncorhynchus mykiss). Aquaculture, 384-387: 46-55.

Muhlia-Almazán, A., A. Sánchez-Paz, F.L. GarcíaCarreño. 2008. Invertebrate trypsin: a review. J. Comp. Physiol. B, 178: 655-672.

Navarrete del Toro, M.A., F.L. García-Carreño \& J.H. Córdova-Murueta. 2011. Comparison of digestive proteinases in three penaeids. Aquaculture, 317: 99106.

Navarrete del Toro, M.A., F. García-Carreño, M. DíazLópez, L. Celis-Guerrero \& R. Saborowski. 2006.
Aspartic proteinases in the digestive tract of marine decapod crustaceans. J. Exp. Zool., 305A: 645-654.

Oh, E.S., D.S. Kim, J.H. Kim \& H.R. Kim. 2000. Enzymatic properties of a protease from the hepatopancreas of shrimp, Penaeus orientalis. J. Food Biochem., 24: 251-264.

Oppert, B., T.D. Morgan, K. Hartzer, B. Lenarcic, K. Galesa, J. Brzin, V. Turk, K. Yoza, K. Ohtsubo \& K.J. Kramer. 2003. Effect of proteinase inhibitors on digestive proteinases and growth of the red flour beetle, Tribolium castaneum (Herbst) (Coleoptera: Tenebrionidae). Comp. Biochem. Physiol. C, 134: 481-490.

Paschke, K., J.P. Cumillaf, M.E. Chimal, F. Díaz, P. Gebauer \& C. Rosas. 2013. Relationship between age and thermoregulatory behavior of Lithodes santolla (Molina, 1782) (Decapoda, Lithodidae) juveniles. J. Exp. Mar. Biol. Ecol., 448: 141-145.

Pereda, S.V., I. Uriarte \& J.C. Cabrera. 2009. Effect of diet and paralarval development on digestive enzyme activity in the cephalopod Robsonella fontaniana. Mar. Biol., 156: 2121-2128.

Perera, E., F.J. Moyano, M. Díaz, R. Perdomo-Morales, V. Montero-Alejo, L. Rodríguez-Viera, E. Alonso, O. Carrillo \& G.S. Galich. 2008. Changes in digestive enzymes through developmental and molt stages in the spiny lobster, Panulirus argus. Comp. Biochem. Physiol. B, 151: 250-256.

Rojo, L., F. García-Carreño \& M.A. Navarrete del Toro. 2013. Cold-adapted digestive aspartic protease of the clawed lobsters Homarus americanus and Homarus gammarus: biochemical characterization. Mar. Biotechnol., 15: 87-96.

Rojo, L., A. Muhlia-Almazan, R. Saborowski \& F. GarcíaCarreño. 2010. Aspartic cathepsin D endopeptidase contributes to extracellular digestion in clawed lobsters Homarus americanus and Homarus gammarus. Mar. Biotechnol., 12: 696-707.

Rossano, R., M. Larocca \& P. Riccio. 2011. Digestive enzymes of the crustaceans Munida and their application in cheese manufacturing: a review. Mar. Drugs, 9: 1220-1231.

Saborowski, R., G. Sahling, M.A. Navarrete del Toro, I. Walter \& F.L. García-Carreño. 2004. Stability and effects of organic solvents on endopeptidases from the gastric fluid of the marine crab Cancer pagurus. J. Mol. Catal. B-Enzym., 30: 109-118.

Saborowski, R., S. Thatje, J.A. Calcagno, G.A. Lovrich \& K. Anger. 2006. Digestive enzymes in the ontogenetic stages of the southern king crab, Lithodes santolla. Mar. Biol., 149: 865-873.

Sarath, G., R.S. De La Monte \& F.W. Warner. 1989. Protease assay methods. In: R.J. Beyon \& J.S. Bond 
(eds.). Proteolytic enzymes: a practical approach. Oxford University Press, New York, pp. 25-56.

Semenova, S.A., G.N. Rudenskaya, L.V. Lyutova \& O.A. Nikitina. 2008. Isolation and properties of collagenolytic serine proteinase isoenzyme from king crab Paralithodes camtschatica. Biochemistry (Moscow), 73(10): 1125-1133.

Siikavuopio, S.I. \& P. James. 2015. Effects of temperature on feed intake, growth and oxygen consumption in adult male king crab Paralithodes camtschaticus held in captivity and fed manufactured diets. Aquacult. Res., 46: 602-608.

Stauffer, C. 1989. Enzyme assays for food scientists. Van Nostrand, New York, 317 pp.

Tapia, I., E. Reyes, A. Lucero, A. Ramos \& M. Cea. 2008. Actualización en la extracción, explotación y consumo de jaiba marmola (Cancer edwardsii) en Chile. Cienc. Trab., 10(28): 50-56.

Received: 24 May 2017; Accepted: 10 October 2017
Teschke, M. \& R. Saborowski. 2005. Cysteine proteinases substitute for serine proteinases in the midgut glands of Crangon crangon and Crangon allmani (Decapoda: Caridea). J. Exp. Mar. Biol. Ecol., 316: 213-229.

Tremacoldi, C.R., R. Monti, H.S. Selistre-De-Araújo \& E.C. Carmona. 2007. Purification and properties of an alkaline protease of Aspergillus clavatus. World J. Microbiol. Biotechnol., 23: 295-299.

Vinuesa, J.H., M.A. Varisco \& P. Balzi. 2013. Feeding strategy of the early juvenile stage of the southern king crab Lithodes santolla in the San Jorge Gulf, Argentina. Rev. Biol. Mar. Oceanogr., 48(2): 353-363.

Woll, A.K. \& G.M. Berge. 2007. Feeding and management practices affect quality improvement in wildcaught edible crab (Cancer pagurus). Aquaculture, 269: 328-338.

Zar, J.H. 1996. Biostatistical analysis. Prentice Hall, New Jersey, 662 pp. 